\title{
PURE BLOOD STATUTES \\ IN SIXTEENTH CENTURY TOLEDO: \\ IMPLEMENTATION AS OPPOSED TO ADOPTION *
}

LINDA MARTZ

Together with the Inquisition, the pure blood statutes have attracted some of the harshest criticism to be leveled at Early Modern Spain '. Designed to exclude any individual not descended from Old Christians, adoption of these statutes by military and religious orders, city councils and cathedral chapters, and colleges and confraternities, began in the fifteenth century and became ever more prevalent after 1520. The statutes were directed against the minorities of Castile, the descendents of Moors and Jews who were considered New Christians because of their relatively recent conversion to Christianity, although as is true with the Inquisition, the descendents of Jewish converts, known also as conversos or confesos, were the primary target.

* I am endebted to The National Endowment for the Humanities for a fellowship that enabled me to write this paper, a version of which was presented at the symposium «In Iberia and Beyond: Hispanic Jews Between Two Cultures" held at the University of Maryland, April 1991.

1 Since the bibliography is extensive, I include here only those works that have been most useful for this article. The most detailed study is A. A. Sicroff, Los estatutos de limpieza de sangre. Controversias entre los siglos XV y XVII, Madrid 1985. H. CH. LEA, A History of the Inquisition of Spain, 1906-1907, [reprint ed., New York 1966]. A. Domínguez OrTiz, Los judeoconversos en España y América, Madrid 1971. J. Caro Baroja, Los judios en la España moderna y contemporánea, Madrid 19782, vol. 2: pt. 4; F. MÁrQuez Villanueva, "Conversos y cargos concejiles en el siglo XV", RABM 63 (1957) 503-540. H. KAMEN, Inquisition and Society in Spain in the Sixteenth and Seventeenth Centuries, Bloomington 1985. J. I. GutiÉRREZ NiETO, "Inquisición y culturas marginadas: conversos, moriscos y gitanos", in El Siglo del Quijote (1580-1680) vol. I, [=Historia de España Ramón Menéndez Pidal XXVI], Madrid 1986, 647-792, 647-727. J.-P. DEDIEU, "Limpieza, pouvoir et richesse: conditions d'entrée dans le corp des ministres de l'Inquisition (Tribunal de Tolède, XVIeXVIIe siècles)", in Les sociétés fermées dans le monde ibérique (XVI-XVIJe s.): Définition et problématique, Paris 1986, 169-187. 
Within Spain there was much debate about the pure blood statutes from the mid-fifteenth on into the seventeenth century. The amount written about the statutes, both pro and con, indicates the depth of feeling they aroused among contemporaries, and A. Domínguez Ortiz is certainly correct in stating that much of the material written against the statutes has been lost ${ }^{2}$. These debates, which usually went hand-in-hand with the adoption of statutes, have attracted the attention of modern scholars. Frequently absent from the discussions of theory and the increasingly lengthy list of institutions that adopted statutes are examples of how the pure blood statutes functioned after they were imposed, and if they did achieve the stated goal of eliminating conversos. In some cases, adoption appears to be equated with implementation, and it is argued that in the sixteenth century conversos were deprived of access to posts of honor in both church and state ${ }^{3}$ and that the pure blood doctrine was "so important that a serious barrier to status mobility was created" 4 . However, an analysis of the implementation of the pure blood statutes may lead to a different assessment of their effectiveness and the impact they had upon contemporary Castilian society.

The city of Toledo, with a long history of pure blood statutes and a sizeable converso population, is as good a place as any to look at the process of implementation. By the end of the sixteenth century the city had pure blood statutes in two important institutions, the city council and the cathedral chapter; the latter imposed in 1547 by Archbishop Silíceo, the former by the crown in the 1560 s. In theory at least, by 1600 , if not earlier, descendents of Jewish converts should have been excluded from both these corporations, as well as from numerous religious and all military orders. In practice, conversos could be found in all of them.

The debates about pure blood really began in fifteenth century Toledo, when efforts were made to exclude conversos from the city council s. A pure blood statute was imposed as far back as 1449 ,

${ }^{2}$ A. Domínguez OrTiz, Los judeoconversos, p. 86.

3 J. I. GutiérReZ NieTo, «Inquisición y culturas», p. 716.

${ }^{4}$ H. KAMEN, Inquisition and Society, p. 121.

${ }^{5}$ For details of the Estatuto de Pero Sarmiento, E. Benito Ruano, Toledo en el siglo XV: vida politica, Madrid 1961. F. MÁRQUEZ VILLANUEVA, "Conversos y cargos»; A. A. Sicroff, Los estatutos, pp. 51-56; A. MARTin Gamero, Historia de la ciudad de Toledo, 1862 [reprint ed. Toledo 1979]; N. Round, "La rebelión de 1449", Archivum 16 (1966) 314-51. A document transcribed by A. Martín Gamero (doc. 12) gives the 
when Pero Sarmiento, appointed by Juan II in 1446 to replace Pedro López de Ayala as alcalde mayor of Toledo, led the city into open rebellion. The immediate cause of the uprising was a tax imposed by constable Álvaro de Luna that was to be collected by the converso treasurer, Alfonso Cota ${ }^{6}$. The new impost enraged the tax payers, who first attacked and plundered Cota's house and then other conversos and their property. Afterwards, fourteen conversos were deprived of their municipal offices and, according to the new statute, neither they nor any other converso could ever again hold public office in the city.

Testimonies to the long-term failure of the 1449 statute are numerous. Among the municipal office holders who signed an ephemeral peace treaty in 1458 are several easily identifiable converso names: Fuente, Arroyo, Quadra, Husillo, and Juan Álvarez de Toledo-Zapata, father of the future crown secretary, Hernán Álvarez de Toledo-Zapata '. More evidence is given in 1468 when, after another outbreak of street fighting, fires and pillaging in 1467, conversos were again deprived of their public offices, which obviously means they had regained admission to the city council.

Most historians agree that in the fifteenth century the implementation of pure blood statutes in the city council was a failure. The statutes may serve as an indication of increasing anti-Semitism, but they did not serve as a means of keeping conversos out of the Toledo city government. The issue of pure blood in the city council did not come up again until the 1560s, but meanwhile the conversos had other preoccupations, given that in 1485 the Inquisition was

number of persons removed from office in 1449 as eleven, the number adopted by $F$. Márquez Villanueva. According to A. A. Sicroff (p. 55, note 39) and a document transcribed by E. Benito Ruano (doc. 16), the number is fourteen.

${ }^{6}$ N. Round, The Greatest Man Uncrowned: A Study of the Fall of don Alvaro de Luna, London 1986. F. CANTERA BURgos, El poeta Rodrigo Cota y su familia de judios conversos, Madrid 1970, for details of the tax collector and his family.

7 E. Benito Ruano, op. cit., doc. 31 for the 1467 peace accord and doc. 47 for the removal of converso regidores in 1468. Sources used to identify converso surnames are: P. León Tello, Judios de Toledo, Madrid 1979; J. C. Gómez-Menor, Cristianos nuevos y mercaderes en Toledo, Toledo 1971. F. CANTERA BURGOS and P. LEÓN Tello, Judaizantes del arzobispado de Toledo habilitados por la Inquisición en 1495 y 1497, Madrid 1969. F. MÁrQUEZ VillanUEVA, Investigaciones sobre Juan Álvarez Gato: Contribución al conocimiento de la literatura castellana del siglo XV, Madrid 1960, for the Toledo-Zapata clan. F. Cantera Burgos, Cota. L. MarTZ, "Converso Families in Fifteenth and Sixteenth Century Toledo: The Significance of Lineage", Sefarad XLVIII (1988) 117-196. 
established in Toledo ${ }^{8}$. This institution provided yet another means of keeping conversos out of the city council, since anyone punished by the Holy Office was automatically deprived from holding public office. It was the lower-- and middle-class conversos who received the brunt of the Inquisition's public attack in the early years ${ }^{9}$, not those with important aristocratic or royal connections who either escaped completely or frequently availed themselves of a secret reconciliation with the church. But in later years, even the descendents of those publicly punished by the Inquisition managed to overcome this stigma. Descendents of the jurados, notaries, merchants, and tax collectors whose names appear on the list of those reconciled or punished in 1486 or later, reappear in the city government in the sixteenth century, sometimes with the same surname, sometimes with another.

One example of such a success story is a family that used the name Santo Domingo, with the occasional addition of Herrera. Gutierre de Santo Domingo, a trapero by profession, was one of the thousands of Toledo conversos reconciled in $1486{ }^{10}$. Both he and his wife formed part of the group reconciliation ceremonies that occurred after «The Time of Grace». Gutierre was accused of observing such Jewish practices as lighting candles on Friday night, celebrating Passover, eating unleavened bread and cooking special meals, dressing in clean clothes on Saturday, and blessing his children in a Jewish manner.

One of Gutierre's sons, Diego de Santo Domingo, managed to escape any contact with the Inquisition, possibly because he was too young, or possibly because he left town before the Holy Office arrived in Toledo ". A cloth merchant by trade, Diego, died in 1548. He and his wife, Inés Álvarez Cota, a member of the far-flung

${ }^{8}$ For some of the bibliography relating to the Inquisition's early years in Toledo, see notes 1 and 7. Also F. FITA, "La Inquisición toledana. Relación contemporánea de los autos y autillos que celebró desde el año 1485 hasta el de 1501", BRAH XI 291-310. B. BENNASSAR, Inquisición española; poder politico y control social, Barcelona 1984. J.-P. DEDIEU, L'administration de la foi: L'Inquisition de Tolède XVIe-XVIIIe siècle, Madrid 1989.

9 Y. BAER, A History of the Jews in Christian Spain, Philadelphia 1961-1966, vol. 1, p. 344.

${ }^{10} \mathrm{~A}$ (rchivo) H(istórico) N(acional), Inquisición, leg. 143, exp. 21, fol. 26, 16 June 1485.

${ }^{11}$ Information about the Herrera-Santo Domingo family is taken from a study I have in progress. 
Cota clan of Toledo, left behind two sons, Gutierre de Santo Domingo and Juan de Herrera y Santo Domingo, both merchants. The eldest son Gutierre died in 1554. This left the younger brother Juan as head of the family and the family business, which he ran with great acumen and profit, eventually becoming a wholesaler who dealt in a variety of products and merchandise, as well as a source of loans for those in need of cash.

In 1557, at about forty-seven years of age, some seventy years after his grandfather had been reconciled by the Inquisition, Juan de Herrera y Santo Domingo was able to buy for himself the office of regidor in Toledo ${ }^{12}$. Not surprisingly, after he became a regidor, Juan de Herrera dropped the Santo Domingo portion of his surname, as that was the name associated with the Inquisition punishment. However, the name Herrera was very popular with Toledo conversos, and few local people were ignorant of his origins. The apparent ease with which Juan de Herrera purchased his office underlines a basic element of Castilian society that counted for much in overcoming dubious lineage: money.

To support his wars against heretics, Charles $\mathrm{V}$ needed immense sums of money, and the Castilian Council of Finance resorted to all sorts of creative money-raising schemes to find these sums ${ }^{13}$. In the 1540s and 1550s aristocrats and prelates were pressed for donations to the crown, juros (state bonds) were sold in abundance, and villages, titles of hidalguia (patents of nobility), and public offices were sold to those who could afford to buy them. However, in the 1550 s, sales of some of these items were not going as well as had been anticipated. From Jaén, Diego de Córdoba y Mendoza wrote the crown that he had no luck selling hidalguias in that city, he thought because the purchase of a municipal office was cheaper and

${ }^{12}$ A(rchivo) G(eneral) de S(imancas), C(onsejos) y J(untas) de H(acienda), leg. 31, fol. 155: Copy of a document notarized in Toledo, 11 May 1557, by Pedro de Uzeda.

${ }^{13}$ For the details about the sad state of royal finances and efforts to raise more money, see R. CARANDE, Carlos $V$ y sus banqueros, Madrid 1965-1967, vol. III, chaps. 3 and 4. M. UlloA, La hacienda real de Castilla en el reinado de Felipe II, Madrid 1977 , chaps. 4 and 22. A. Domf́nguez ORTIZ, «La venta de cargos y oficios públicos en Castilla y sus consecuencias económicas y sociales", in IDEM, Instituciones y sociedad en la España de los Austrias, Barcelona 1985, 146-183. For the wide variety, number and cost of offices sold, see M. CUARTAS RIVERo, "La venta de oficios públicos en el siglo XVI", Actas del IV Symposium de Historia de la Administración, 1982, Madrid 1983?, 225-260. 
achieved the same end, which was to pay no taxes ${ }^{14}$. According to his report, a medical doctor had offered 4,000 ducats for all three municipal offices to be sold in Jaén, while another individual was willing to pay 800 ducats a piece for the three notarial offices to be sold.

In Toledo the crown operative was the regidor Rodrigo Niño, who reported, on 24 March 1557, that he was having little success in selling any of the 150 titles of hidalguias the crown hoped would be purchased by "persons of wealth and property" is. The prospective buyers all responded that they did not need to buy hidalguia because by living in Toledo they enjoyed hidalguia through the privileges and liberties given the city by past monarchs. To this Rodrigo Niño pointed out that one day they might have to leave Toledo and, if they did, they and their children would be taxpayers. However, «neither this reason nor many others that I gave were sufficient to move even one of them to pay a real for hidalguia» ${ }^{16}$. The only item on the list that elicited interest was the sale of municipal offices.

The reaction of the prospective purchasers, who wanted the best value for their money and were not seduced by the prospect of nobility but were attracted by tax exemption, suggests that the group being appealed to in 1557 was largely of middle class origins. From the crown's point of view, the sale of municipal offices to the men of commerce, trade and finance afforded an opportunity to tap the resources of these prosperous citizens. For the purchaser, a municipal office offered many attractions aside from tax exemption. As a regidor, he would be able to take part in and possibly influence local politics, as well as increase his income by participating in the

\footnotetext{
14 AGS, CJH, leg. 30, fol. 230.

15 The sale of hidalguia by the crown has been scrutinized by I. A. A. THOMPSON, "The Purchase of Nobility in Castile, 1552-1700", The Journal of European Economic History 8 (1979) 313-360; and IDEM, "Neo-noble Nobility: Concepts of hidalguia in Early Modern Castile», European History Quarterly 15 (1985) 379-406.

16 AGS, CJH, leg. 23, fol. 205, 24 March 1557. This quotation is also cited by I. A. A. Thompson, "Purchase of Nobility", p. 354, note 139; however the person who wrote to the crown is Rodrigo Niño, not Pedro Niño. F. H. A. Al-Hussein, "Los mercaderes de Medina: Personalidad, actividades y hacienda", in E. LoRENzo SANZ (coord.), Historia de Medina del Campo y su tierra, vol. 2, Medina del Campo 1986, 158-161. Based on the fact that the merchants of Medina del Campo were already exempt from paying taxes, the author argues that the tax-exempt status conferred by municipal offices has been over emphasized, but tax exemption does appear prominently in the Simancas documentation for the 1550 sales.
} 
numerous deficit-financing schemes organized by the city council. And even if the office holder preferred not to attend the council meetings, the title of regidor made him a member of the local ruling oligarchy, which conferred a fair degree of social status and prestige within the community. Finally, since municipal offices could be sold or transmitted to one's heirs, they were a good long-term investment.

The crown's lack of success in selling hidalguia in the $1550 \mathrm{~s}$ is partially explicable in terms of their high price: 5,000 ducats for hidalguia as opposed to 1,800 ducats for a regiduría in Toledo. Yet another explanation is that hidalguia could be acquired by other means. An hidalgo, literally a son of someone, occupied the lowest echelon of the noble estate ". The best way to acquire hidalguia was through blood lines, known as hidalguia de sangre. Barring this good fortune, it could also be purchased from the crown, never a popular method judging by the small number of patents of nobility sold ${ }^{18}$. A more favored recourse was an appeal to the chancellery or appeal courts, in the case of Toledo the chancellery of Valladolid, which would issue to successful litigants cartas ejecutorias, leading to the creation of hijosdalgo de ejecutoria ${ }^{19}$. Contemporaries knew and distinguished between hidalguía de sangre and hidalguia de ejecutoria, the former being the most admired but the latter also served some useful purposes for the owners.

The number of offices available in the Toledo city council varied. Ideally, there were twenty-four regidores and two jurados for each parish, but these numbers fluctuated dramatically according to the financial needs and strength of the crown. In the fifteenth century the numbers rose to an all-time high in 1475 when there were fifty-

17 This brief synopsis is based on A. Domínguez OrTIz, El Antiguo Régimen: Los Reyes Católicos y los Austrias, [= M. ARTOLA (dir.), Historia de España Alfaguara III], Madrid 1988, pp. 160-165. See also M.-C. GerBeT, La nobleza en la corona de Castilla: sus estructuras sociales en Extremadura (1454-1516), Cáceres 1989.

18 The low esteem in which patents of nobility were held is vivid when compared with other means of attaining social status. I. A. A. THOMPSON, "Purchase of Nobility", p. 357, estimates that from 1552 to 1699 between 219 to 253 patents of nobility were sold, whereas between 1600 and 1699 some 9,486 habits were awarded by the three military orders; see E. Postigo Castellanos, Honor y privilegio en la Corona de Castilla, el Consejo de las Órdenes y los Caballeros de Hábito en el s. XVII, Valladolid 1988, pp. 198-200.

${ }^{19}$ For details of this process in the chancellery of Granada, see J. FAYARD - M.-C. GERBET, «Fermeture de la noblesse et pureté de sang en Castille a travers les procès de Hidalguía au XVIe siècle», Histoire, Économie et Société 1 (1982) 51-75. 
two regidores and seventy-five jurados ${ }^{20}$. The number of regidores was slowly reduced to the original twenty-four by the Catholic Kings, but throughout the sixteenth century it increased. Charles V added a total of fifteen new regidurias in Toledo; three in 1543, four in 1549, and eight in 1557. Philip II added more, and in 1581 there were thirty-six regidores, twenty-five who sat on the noble's bench and eleven who sat with the citizens. This excludes six officials -three alcaldes (mayor, de las alzadas, de mesta), an alferez, an alguazil mayor, and a depositario-general - who all had the right to sit and vote in the municipal council, making a total of forty-two individuals who comprised the city council, nearly double the desired number ${ }^{21}$. As is true with most offices of the period, those of regidor and jurado were considered as personal property that could be either sold or transmitted to one's heirs. In the sixteenth century the crown had the right to approve the transmission of these offices, but it was rare that the office holder's wishes were not respected.

The crown might have viewed the selling of municipal offices as a convenient way of raising money, but many regidores of the Toledo city council were not enthusiastic about the scheme ${ }^{22}$. When the issue was debated in 1549, Rodrigo Niño was one of only two regidores who supported the plan, with twelve regidores opposed. Those opposed argued that the Catholic Kings had limited the number of regidores in Toledo to twenty-four, and when taking their oath of office they had sworn to uphold this limitation. In 1543, when the first sale of three new offices had occurred, they had agreed only on the condition that three existing offices be eliminated to maintain the correct number. Since this had not been carried out,

${ }^{20}$ F. Cantera Burgos, Cota, p. 11; P. DE Alcocer, Historia o descripción de la imperial ciudad de Toledo, 1554 [reprint ed. Toledo 1973], fols. 92-93. A(rchivo) M(unicipal) de $\mathrm{T}$ (oledo), "Libro de la razón de los corregidores, dignidades y regidores... desde 17 de enero del año 1471 [hereafter AMT, Libro de regidores], sala 1, núm. 132, nf. Beginning in 1507, this manuscript contains continuous information about regidores; information for the fifteenth century is limited. The jurados of the city have been studied by F. J. ARANDA PEREZ, Poder municipal y el cabildo de jurados de Toledo en la edad moderna, Toledo 1992. I would like to thank the author for allowing me to read the typescript of this study before publication.

${ }^{21}$ AGS, D(irección G(eneral) del T(esoro), Inv(entario) 24, leg. 322, nf: Toledo, Relación de los oficios que escribió el corregidor avia el año de 1581; AMT, Libro de regidores.

22 AGS, CJH, leg. 20, fols. 83 and 84. The last document is a copy of the municipal acts of 12 June 1549 that records how each regidor voted. 
they were unwilling to accept the sale of any new municipal offices. Whatever the opinion of the Toledo city councillors, who had an obvious interest in maintaining a limited number, the crown continued to sell municipal offices ${ }^{23}$.

In Toledo the crown handled these sales somewhat indirectly. Equal numbers of new seats were given to the two leading local aristocratic families, the Silva and the Ayala, counts of Cifuentes and Fuensalida, respectively, and they in turn sold them to others. This strategy worked to the benefit of the local leaders, who could build up their patronage network and still maintain a balance of power in the city council. The crown, however, got the money, which is not to say that the local élites did not collect some additional money. Juan de Herrera bought his seat from the Ayala clan, specifically caballero don Alonso Manrique de Ayala, a brother of the 4th count of Fuensalida, Pedro López de Ayala. The cost of the office was 1,800 ducats ${ }^{24}$.

Juan de Herrera was not the only converso in the Toledo city council in the 1550s and 1560s. Limiting the discussion to those whose converso origins are reasonably well established, there is Gaspar Sánchez Franco, who also purchased a regiduria in 15572 . Two others of the Franco clan, Hernán Franco and Alonso Franco, bought seats in 1548 and 1563, respectively. In 1549, Francisco Sánchez de Toledo, a relative of the Cepeda clan later made famous by Saint Teresa, bought an office from Juan de Alarcón. In 1529

${ }^{23}$ According to AGS, CJH, leg. 35, fol. 224, the 1557 sales in Toledo brought in a total of $6,619,750 \mathrm{mrs}$.; 4,725,000 mrs. for eight new regidurias, and 1,893,750 mrs. for eight new offices of jurados. However, this document is not the final copy and these figures may be too low. M. CUARTAS Rivero, "Venta", p. 242, gives a total of $65,764,750 \mathrm{mrs}$. for the 1557 sale of regidurías and veinticuatrías throughout Castile.

${ }^{24}$ AGS, CJH, leg. 31, fol. 155: Copy of a document notarized in Toledo, 11 May 1557 , by Pedro de Uzeda. The original cost of the office was 1,600 ducats, later raised to 1,800 ducats.

${ }^{25}$ AMT, Libro de regidores. Since this manuscript has no folio numbers, the awkward system of distinguishing by number (one to twelve), location (right or left), and age (old or new, that is, acrecentados) of the offices has been retained. Gaspar Sánchez Franco, whose name is frequently and mistakenly given as Gaspar Suárez Franco, got the fifth new regiduria on the left. Hernán Franco, eighth old seat on the left. Alonso Franco fifth old seat on the left. Francisco Sánchez de Toledo, sixth old seat on the right. Juan de la Torre, twelfth old seat on the right. Diego de San Pedro, eleventh old seat on the left. Diego Hurtado, seventh old seat on the left. For the origins of these families, see note 7; also S. GILMAN, The Spain of Fernando de Rojas. The intellectual and social landscape of La Celestina, Princeton 1972, pp. 498503 , for a brief genealogy of some of the Franco family. 
Juan de la Torre bought a regiduría from Álvaro de Ayala, while in 1544 Diego de San Pedro bought a seat from Pedro Zapata, a descendent of the family of the crown secretary Hernán Álvarez de Toledo-Zapata. In 1562 Diego Hurtado bought an office from Pedro Niño de Rivera, a son of María Niño and the Aragonese crown secretary, Lope Conchillos.

The Toledo city council was divided into two benches of regidores, one for nobles (caballeros), the other for citizens. The citizen's bench was dominated by conversos of the middling sort who had not yet had time, opportunity, money, or desire to intermarry with the local aristocrats. This is the bench where Juan de Herrera and all the men mentioned above sat. However, some wealthy conversos sat on the noble's bench. In 1534, after a bitter legal battle with many in the Toledo city council that had dragged on from at least 1529, Hernando Álvarez Ponce' de León, a grandson of the crown secretary Hernán Álvarez de Toledo-Zapata, was finally given a seat on the noble's bench ${ }^{26}$.

Juan de Herrera had been in office for less than ten years when the crown decided to impose pure blood statutes in the Toledo municipal council ${ }^{27}$. The first royal letter arrived in Toledo in March 1566. It stipulated that those on the noble's bench were to be «hijosdalgo de sangre», whose parents had not had a "mechanical or vile office" presumably meaning they had not been involved in manual labor or commerce. Those on the citizen's bench had to be "hijosdalgo or at least Old Christians, of pure blood, with no trace of Moor or Jew». For the citizen regidores the onus of having held a vile or mechanical office was to be pardoned, but the pure blood qualification would eliminate many of them. As is true with most of the sixteenth century pure blood statutes, the determination of these qualities was to occur after the initial office holder died and the

${ }^{26}$ AMT, Libro de regidores, eighth old on right: Jerónimo Román de Higuera, "Familias de Toledo", R(eal) A(cademia) de la H(istoria), cod. 9/229, fols. 227-232, gives details and some of the documents relating to the lengthy litigation.

${ }^{27}$ The pure blood statute of 1566 is mentioned by A. DE CASTRO «Discurso preliminar", en Obras escogidas de filósofos, BAE 65, Madrid 1929, p. LIX. A. Domínguez-Ortiz, Conversos, pp. 242-43. J. Caro Baroja, los judios, vol. 2, p. 310. J. I. GutiérReZ NiETO, "Inquisición y culturas", pp. 710-711. E. LORENTE TOLEDO, Gobierno y administración de la ciudad de Toledo y su término en la segunda mitad del siglo XVI, Toledo 1982, pp. 123-126, includes a copy of the 1566 crown letter. The second letter, and the response of the city council, are taken from AMT, Libro de regidores. 
municipal office was resigned to his heir or sold to another person. At this point, the new candidate was to present to the Toledo corregidor a report of his qualities and genealogy, which would then be scrutinized by the Cámara Real.

The 1566 crown letter also called for a reduction in the number of regidores on both benches; the nobles would have sixteen seats, the citizens only eight seats. If enforced, the reduction of seats, combined with the new personal qualifications, would deprive many of their municipal offices. But there was not a great flurry of activity to enforce the new ruling. To the royal order of 1566 the city council responded by doing nothing, and the order was suspended in April of that year. Yet another order to the same effect arrived in April of 1569, and this inspired some efforts to compliance, although it is impossible to say exactly what. In 1594 the city council consisted of forty-four individuals, twenty-eight regidores on the noble's bench, ten on the citizens bench and six officials, which was double the number specified by the crown order of the $1560 \mathrm{~s}{ }^{28}$.

What prompted the new order for the Toledo city council? The explanation given by the crown was the avoidance of "differences, litigation, and passions" that had caused much «uneasiness and anxiety" in the city and the city council. But surely this is specious reasoning. If the issues of who was qualified to become a regidor and what bench they were to sit on had created discord and strife in the past, which they certainly had, the imposition of a pure blood statute on the citizen's bench would certainly exacerbate these problems. It may be that this new ruling was nothing more than another stratagem for extorting money from the office holders, who would be forced to have their nobility confirmed either by the crown or the chancellery courts, or pay more in bribes to have their lineage certified locally. That the crown continued to sell titles of hidalguias and offices to those who could afford them, including conversos, suggests that the money raised through these sales was too tempting to abandon. Hernán Suárez Franco, yet another of the numerous Franco clan, became a regidor in 1576 and purchased a patent of nobility in $1569{ }^{29}$. And after nearly twenty years of litigation and appeals, another converso family finally secured a place on the

${ }^{28}$ AGS, DGT, Inv. 24, leg. 322, nf.

${ }^{29}$ AGS, DGT, Inv. 5, leg. 1, fol. 37, 23 February 1569, for the patent of nobility which cost 5,000 ducats; AMT, Libro de regidores, fifth new regiduría on left. 
noble's bench when Antonio Álvarez de Alcocer was admitted as a noble regidor in $15833^{30}$.

Juan de Herrera, however, made no effort to invest in hidalguía, even though he could certainly have paid the price. Aside from being deterred by the thought that purchased nobility was too expensive for the rewards it brought, he might also have felt there was an element of risk in seeking a patent of nobility, which would involve some amount of possibly compromising genealogical research. On the other hand, if the Toledo-Zapata, the Franco, and the Alcocer families were successful in passing the test, surely every converso in Toledo could hope to pass.

It is also possible that Juan de Herrera and some of his fellow citizen regidores were proud of their middle class background, believed that commerce and business activities were useful and respectable, and did not aspire to nobility. This interpretation seems implicit in the protests presented to the crown against the 1566 statute by some citizen regidores, including Juan de Herrera, Francisco Sánchez de Toledo, Diego Hurtado, and three members of the Franco clan ${ }^{31}$. Starting with the premise that the citizen regidores knew more about the problems of the city and took a greater interest in the municipal council than the nobles, they argued that a decrease in the number of citizen regidores would leave the city less well governed. The truth of this assertion must await a more detailed study of the Toledo city council, but given their experience in the business world, it is certain that these men had a better understanding of the city's finances than many nobles. What the protest does make clear is that in the 1560 s the citizen regidores were confident of their abilities and talents, and their contribution to the well-being of their native city.

Aside from their converso origins, the men who wrote against the 1566 statute shared other traits. Excluding Diego Hurtado, whose personal life is not well enough known, their careers are similar. Having amassed a comfortable fortune through business and trade, they were the "new rich" of the mid-sixteenth century,

${ }^{30}$ AMT, Libro de regidores, third new office on the left.

31 A. DE CASTRO, "Discurso", p. LIX, note 2, gives the names of the regidores and some of their complaints based on a document in the RAH, Colleción Salazar, L-5. Also J. I. Gutíkrez Nieto, «Inquisición y culturas», pp. 710-711, and A. Dominguez-Ortiz, Conversos, p. 243, for some perceptive comments about motives. 
who invested some of their wealth in improved social status and political influence through the purchase of a municipal office. As regidores, some exercised important civic responsibilities. During his first years in office, Juan de Herrera was responsible for much of the financing involved in buying the grain that fed a hungry populace during the famine and sickness of 1557 and 1558, and Francisco Sánchez de Toledo served as a procurador to the Castilian Cortes in 1569. To describe these men as forming part of a marginal group within Toledo society seems inappropriate in view of their economic achievements, their social mobility, and their political participation. In $f_{c}$ ct, it may have been their success on the local level that caused a backlish against them in the form of the 1566 pure blood statute. For blool lines were one area in which these men remained unassimilated and thus open to attack. They were married to, and their children married, spouses of other known converso families, which is to say that they did not try to escape their origins by marrying into the relative safety of those reputed to be of pure blood. For whatever reasons, they preserved their ethnic origins within the family.

Juan de Herrera and his wife, Leonor de Alcocer, had thirteen children baptized, ten of whom lived to be adults ${ }^{32}$. All the spouses of the seven children who married were of converso origins, some from Toledo, others from more distant points. Of interest here are Juan de Herrera, Jr., the youngest son who eventually inherited his father's office of regidor, and the second daughter, Jerónima de Herrera, who married Francisco Sedeño de Mesa, an outsider from Albacete.

Exactly how the Herrera-Santo Domingo clan came into contact with the Albacete family is unknown, but Francisco Sedeño did not arrive in Toledo without resources or contacts. He was a regidor of Albacete, and his father, Gabriel de Espinosa, had his hidalgo status confirmed by the Granada chancellery sometime before his death in 1559. Francisco's mother, Isabel de Solís, lived on forty years longer in Albacete, skillfully managing the family investments.

In a world where family contacts counted a great deal in achieving success, it is worth exploring the family network of Gabriel de Espinosa, for he had two influential relatives. One was Sebastián

${ }^{32} \mathrm{~A}$ (rchivo) de la $\mathrm{P}($ arroquia) de $\mathrm{S}(\mathrm{an}) \mathrm{N}$ (icolás), Libros 1,2 de bautismos de San Vicente. 
Ramírez de Sedeño y Fuenleal, a comendador of a military order and a regidor of Toledo as of $1558{ }^{33}$. Another was a cleric, Diego Ramírez de Sedeño y Fuenleal ${ }^{34}$. In 1559 Diego Ramírez was also in Toledo as an inquisitor, and he was active in the arrest of the new Toledo archbishop, Bartolomé Carranza. In 1561 Diego Ramírez was appointed bishop of Pamplona and a year later left to attend the Council of Trent. He was accompanied on the journey by his brother Sebastián, who formed part of an eighteen-person entourage, one of the largest in Trent.

The exact origins of the bishop of Pamplona are unknown, but he was a relative of a man who had been bishop of Cuenca, Diego Ramírez de Villaescusa. This family boasted an impressive record in church appointments from the late-fifteenth to the mid-sixteenth century, with a total of six prelates. What the prelates had in common was their birthplace in the village of Villaescusa de Haro, in the present-day province of Cuenca. As a biographer put it, "They called Villaescusa 'the fortunate', and it truly was ... as in little more than fifty years it gave to the church seven great prelates, all of the same family and surname» ${ }^{35}$.

The first of the dynasty was Dr. Gil Ramírez de Cuenca, who died before he could take possession of the diocese of Calahorra. Next was García Ramírez de Villaescusa, bishop of Oviedo when he died in 1508. He was an older brother of Diego Ramírez de Villaescusa who became dean of Granada and Seville, senior chaplain of Queen Juana and her spouse Philip the Fair, successively bishop of Astorga (1498), Málaga (1500), and Cuenca (1518-1537), president of the chancellery court in Valladolid at the time of the Comunero

${ }^{33}$ AMT, Libro de regidores, ninth old on right. Sebastián Ramírez is mentioned as a comendador in A(rchivo) $\mathrm{H}$ (istórico) $\mathrm{P}$ (rovincial) de T(oledo), Prot. 1507, fols. 242246, 16 January 1560 , but I have been unable to locate him in any of the military orders.

${ }^{34}$ For Diego Ramírez de Sedeño, see J. GoÑ I GazTAMBIDE, Los navarros en el concilio de Trento y la reforma tridentina en la diócesis de Pamplona, Pamplona 1947, chap. 5; J. I. TelleCheA Idigoras, El arzobispo Carranza y su tiempo, Madrid 1968, 1, pp. 105-106, 108, 198, 236-238.

${ }^{35}$ F. G. Olmedo, Diego Ramírez Villaescusa (1459-1537), Madrid 1944, p. 4 for the quote and the beginning of the family history which continues to p. 7. The quote mentions seven prelates, but one of these men did not become a prelate. While the family genealogy is difficult to confirm, the ecclesiastical appointments can be confirmed by entries in Q. AldEA et al. (eds.), Diccionario de Historia Eclesiástica de España, Madrid 1972-1987. I have not located entries for Dr. Gil Ramírez de Cuenca or Dr. Pedro Ramírez de Arellano. 
revolt, and founder of a college in Salamanca. A nephew of Diego Ramírez was Antonio Ramírez de Haro, bishop of Orense (1537), Ciudad Real (1539), Calahorra (1541), and Segovia (1543) where he died in 1549.

Another family member was Sebastián Ramírez de Fuenleal, who began his episcopal career in the New World as bishop of Santo Domingo, and was later appointed president of the first audiencia of Mexico. Returning to Spain, he became bishop of Tuy (1538), León (1539), president of the council of the Indies, and bishop of Cuenca (1542) before his death in 1547. He would appear to be the namesake of the comendador who became a Toledo regidor in 1558 .

The bishop of Cuenca, Diego Ramírez de Villaescusa, had a nephew named Pedro Ramírez de Arellano, a doctor in both civil and canon law. He gave up a church career because his uncle named him heir to an estate he had built up that included lordship (señorio) of three villages. His marriage to Leonor de Mendoza de Guzmán, a sister of the count of Orgaz, Alvar Pérez de Guzmán, should have brought him into contact with the local politics and society of Toledo. His name suggests that this family of prelates may have been related to Dr. Alonso Ramírez de Arellano, also known as «de Villaescusa». who served as corregidor in Valladolid for thirteen years and had numerous contacts within the city of Toledo ${ }^{36}$.

The last person mentioned in this lengthy chain of ecclesiastical achievers from Villaescusa de Haro is the bishop of Pamplona, Diego Ramírez de Sedeño, who at the Council of Trent supported the authority of the bishops, the need for seminaries, and, most ardently, the Inquisition. His efforts to implement the Tridentine decrees in his diocese of Pamplona quickly became bogged down in lawsuits and squabbles with the cathedral chapter and other vested interests, which the prelate's litigious and combative nature did little to assuage. Diego Ramírez was a good man to have on one's side in an argument, and as a first cousin of Gabriel de Espinosa, the

${ }^{36}$ L. Martz - A. Franco Mata, "La capilla de Sancho Sánchez de Toledo", Carpetanía 1 (1987) 203-216, 207. Dr. Alonso Ramírez de Arellano, or de Villaescusa, served as a judge of the goods confiscated from those punished by the Inquisition, he may be the Dr. Villaescusa who was a Toledo regidor in 1507, and his daughter married into an important converso family that used the name Sánchez de Toledo. 
father of Francisco Sedeño y Mesa, the young bridegroom could boast a powerful relative.

Francisco Sedeño and Jerónima de Herrera were officially betrothed in Toledo on January 16, 1560, and married in August 1560 , a memorable year in Toledo history because of the presence of the King and the Court for the last meeting of the Castilian Cortes to be held in the Imperial City ${ }^{37}$. Aside from the financial matters concerning the dowry, the group who worked out the details of the marriage contract agreed that Francisco Sedeño should become a regidor of Toledo, and most of those in attendance donated cash toward the purchase of this office. That all parties took for granted the ease of attaining an office of regidor in Toledo, and the means by which to attain it, is notable, although for a variety of reasons this plan was never realized.

The marriage prospered. The couple's first child, Leonor, was baptized in the family parish of San Vicente in April 1562. She was named after her maternal grandmother, Leonor de Alcocer, who attended the ceremony as godmother. Three more daughters were born to the couple, and one son, Gabriel Sedeño y Mesa, born about 1568 in Albacete, who some twenty years later became a candidate for a habit in the relatively small military order of Montesa ${ }^{38}$.

The military orders had various qualifications about the lineage, occupation, and background of prospective candidates, who were to be noble and of pure blood, never to have paid taxes or held a vile office ${ }^{39}$. To assure that the candidate possessed all the necessary qualities on both the maternal and paternal side, each military order usually sent out two of its members to interview witnesses in the various places where the candidate's progenitors were born. These investigations could range from one day of superficial questioning of only a few witnesses to years of questioning that involved

${ }^{37}$ AHPT, Prot. 1507, fols. 242-246, marriage contract for Jerónima de Herrera and Francisco Sedeño, 16 January 1560.

38 APSN, Libro 2 de bautismos de San Vicente. The parish baptismal records for this couple are incomplete, in part because they were in Albacete when some children were born. Aside from Leonor, they had at least three other daughters, Maria (bap. 1569) and Úrsula (bap. 1570) who were baptized in Toledo; another daughter, Jerónima, and a son, Gabriel Sedeño, are not listed.

${ }^{39}$ For a detailed study of the qualifications of the military orders, see E. Postigo Castellanos, Honor y privilegio, especially pp. 133-136. 
hundreds of witnesses, the reading of old documents and parish registers, and the perusal of burial places. In the case of Gabriel Sedeño, the investigation was fast and superficial.

The hearings to establish the qualifications of Gabriel were held in Toledo, Albacete, and the village of San Clemente, in the presentday province of Cuenca, in $1590{ }^{40}$. At this time Jerónima's father, the regidor Juan de Herrera, had been dead for five years, and she was a widow, Francisco Sedeño y Mesa having died sometime before 1577. Jerónima was about fifty years of age, and her son Gabriel Sedeño was about twenty-two years old.

The Toledo hearing was concerned with Jerónima de Herrera and her parents, and the testimony proceeded with boring predictability. The six witnesses included two clerics ${ }^{41}$, one the ninety-yearold parish priest of San Vicente, where the Herrera family had their large, imposing houses; a jurado named Pedro de Manzanos; and Diego Hurtado and Juan Sánchez Cota, both called caballeros of Toledo and both enjoying the prefix of señor, neither of which is accurate. Juan Sánchez Cota, who lived practically next door to the Herrera household, must certainly have been a relative of Jerónima de Herrera, although he is not listed as such. The last witness was Juan de la Cámara, a majordomo of Pedro Zapata de la Cerda, who claimed to be unable to sign his name so he made a cross at the end of his testimony. Given that any majordomo worth his salary would have to be able to sign his name, it seems clear that Juan de la Cámara preferred not to sign his testimony. A man of the same name, and this is an uncommon name in Toledo, served as a witness for the baptism of one of Juan de Herrera's grandchildren in 1575 , suggesting that he was a close friend of the family ${ }^{42}$.

All six witnesses said almost the same thing. Establishing that members of the Herrera family were hijosdalgo either by blood or

${ }^{40}$ AHN, Ó(rdenes) M(ilitares), Montesa, exp. 453, Gabriel Sedeño de Mesa y Herrera, nf. The hearings began in Toledo 23 June 1590 and ended 2 October 1590 in the village of San Clemente. On 18 September 1590, after the hearings in Toledo and Albacete were concluded, Maestre Luis Galcerán de Borja wrote from the Escorial ordering that Gabriel Sedeño be admitted to the order of Montesa.

${ }^{41}$ Ibid. The two clerics are Sr. Gregorio de Maldonado, 44 years, and Sr. Juan Rodriguez, beneficiado of the parish of San Vicente.

42 APSN, Libro 3 de Bautismos de San Vicente. 3 October 1575, baptism of Micaela, daughter of Gaspar del Salto and Úrsula de Herrera, where Juan de la Cámara is a witness. 
by purchase was not easy since Juan de Herrera, Sr., had not availed himself of the opportunity to purchase such a title. The witnesses largely evaded this question by saying that in their dealings and conversation in Toledo, Juan de Herrera and his wife were considered as hijosdalgo. This was feebly buttressed by the fact that the Herrera family was exempt from paying taxes because all citizens of Toledo were exempt from taxes. Other merits mentioned were that neither the candidate nor his father had ever had a vile office, they always lived very nobly and with much honor, and they owned very impressive houses in the city. All the witnesses stated unequivocally that Juan de Herrera and his wife were of pure blood, with no compromising admixtures:

"no les toca ninguna raza ni mescla de moro, judio ni confeso en ningun grado por muy remoto que sea» ${ }^{43}$.

One witness embellished this by pointing out that Juan de Herrera, $\mathrm{Jr}$., a brother of Jerónima, was a regidor of the city, an office that required proof of pure blood on the part of the office-holder.

In Albacete the investigation focussed on the paternal grandparents, Gabriel de Espinosa and Isabel de Solís. Since Gabriel de Espinosa had gone to more expense in certifying their hidalgo status in the Granada chancellery, the five witnesses here had an easy time affirming that the paternal grandparents were indeed hijosdalgo notorios; they had all seen the court document. As well, in 1590 Gabriel Sedeño enjoyed the title of "alguazil mayor of Albacete for the noble estate» certainly another of the numerous offices devised by the crown to sell to those who could afford to buy them. Isabel de Solís was a native of Albacete. Where Gabriel de Espinosa was born is more difficult to determine. Several witnesses said he was born in Villaescusa de Haro, where most of the Ramírez-SedeñoVillaescusa clan originated, but when the last witness mentioned that Gabriel de Espinosa was a native of San Clemente, the investigation team moved there.

The villagers of San Clemente, some of whom were admitted relatives of Gabriel de Espinosa, were equally supportive of the candidate. From them we learn that Francisco Sedeño had been

${ }^{43}$ AHN, OM, Montesa, exp. 453; "any trace or mixture of the blood of Moors, Jews, or confesos for as far back as could be known". 
called "el de Toledo" to distinguish him from another man of the same name, and that Gabriel de Espinosa was a first cousin of the bishop of Pamplona, Diego Ramírez de Sedeño. They also testified that Gabriel de Espinosa was born in the village and his mother was named Catalina González; the name of his father is not given.

With these hearings completed in October of 1590, Gabriel Sedeño was admitted to the order of Montesa and soon thereafter appeared in the streets of Toledo adorned in his new habit. Gabriel's pride in his habit is understandable, but he would have been better off not wearing it in Toledo. Four years later, in a surprising turn of events, his case was re-opened. Possibly this occurred because the order of Montesa, an Aragonese military order, was incorporated into the crown of Castile at the fairly late date of 1587 . This was accomplished with the agreement of the last Master of the order, Luis Garcerán de Borja, marquis of Navarres, but he continued on as Master until his death on March 20, 1593. It may be that Philip II and the Castilian royal bureaucracy waited until this date to complete the actual incorporation, and that it took until 1594 for the complaints about Gabriel Sedeno to surface ${ }^{44}$.

Whatever the cause for the delay, the testimony at the 1594 hearing was much less adulatory about the candidate and his lineage, and the witnesses more numerous and more prestigious. Testimony was presented by a total of twenty-one Toledo witnesses, including the corregidor, Alonso de Cárcoma; the alcalde mayor, señor Juan Gómez de Silva; the alferez mayor and caballero of Santiago, señor Pedro de Silva; the canon and head of the royal chapel of the Reyes Nuevos in the cathedral, Rodrigo de Ávalos; the regidor, Alonso de Rojas; two caballeros of Alcántara, Pedro Manrique de Castilla and Juan Pacheco; the maestrescuela of the cathedral, licentiate Antonio de Covarrubias; and the cathedral canon and administrator of the Hospital of Tavera, Dr. Pedro Salazar de Mendoza. In short, many of the important personages of the city appeared at the second hearing.

The witnesses can be divided into three groups: those who said that Juan de Herrera and Leonor de Alcocer were of Jewish origins; those who said they were not sure of their origins but had heard

44 Á. L. Javierre Mur, Privilegios reales de la orden de Calatrava en la Edad Media. Catálogo de la serie existente en el Archivo Histórico Nacional, Madrid ND., pp. 59-61, gives a brief history of the order of Montesa. 
rumors that they were of Jewish origins; and those who said they were of pure blood, that is, no Jewish blood. The first group was the most numerous with a total of nine witnesses. The second group accounted for five witnesses. This makes a total of fourteen witnesses who stated they either knew or had heard that the candidate's maternal grandparents were of Jewish origins. Only seven witnesses testified to their pure blood.

-Those in the second group - the undecided - kept their observations to a minimum, adopting a fairly common technique of making assumptions based upon decisions already determined by the crown. They pleaded ignorance about the lineage of the regidor Juan de Herrera, Sr., and Leonor de Alcocer, but they assumed that since their son Juan de Herrera, Jr., was a regidor and had to prove his untainted lineage to occupy this office, and since Gabriel Sedeño had already received a habit of Montesa, their lineage must be acceptable. Gossip and doubts about their blood lines had circulated in the city, but they themselves knew nothing certain about this question.

But other were far more certain. The seventy-two-year-old Fernando de Salazar stated that the grandparents of the candidate were descendents of Jews

«...que no los tiene por hombres limpios sino por confessos y descendientes de judios, y que esto es publico y notoria y publica voz y fama. En esta ciudad se escandalizaron mucho de ver en Gabriel Sedeño el habito de tan insigne orden y que se entendio que la informacion que se hizo para darsele se hizo traiendo las partes los testigos" ${ }^{45}$.

Don Hernando Carrillo Osorio went still further by adding that not only was Juan de Herrera, Sr., a descendent of Jews but that he "possessed not a drop of Old Christian blood". Still worse, Juan de Herrera, Sr., had gotten his start in the business world by sweeping a merchant's shop floor:

${ }^{45}$ AHN, OM, Montesa, exp. 453, Gabriel Sedeño de Mesa y Herrera, nf, witness 3, second hearing; "... which is notorious and well known. In this city there was great scandal upon seeing Gabriel Sedeño in the habit of so illustrious an order, and it was understood that the investigation carried out to give it to him was done by paying witnesses to give favorable testimony". 
«Este testigo le tuvo [Juan de Herrera] en este lugar por confesso, descendiente de judios, sin que entendiese jamas que tuviese gota de christiano viejo..." ${ }^{46}$.

Señor Pedro de Silva argued that both sets of grandparents, maternal and paternal, were descendents of Jews:

«Dixo que no solamente los padres de Gabriel Sedeño les tiene por judios pero sus abuelos ansi paternos como maternos les tiene y ha tenido por judios y confessos ... y fue de grave escandalo el dia que le viere con el habito de Montesa y ansi le tiene por incapaz del habito" ${ }^{47}$.

Alonso de Rojas also accused the paternal grandparents of Jewish blood:

«No conocio al padre de Gabriel Sedeño pero entendio que no es christiano viejo ni limpio porque caso con Gerónima de Herrera cuyas hermanas todos [casaron] con confesos y con descendientes de judios; y por buena consequencia se a de entender y sospechar que el padre de Gabriel Sedeño era confeso, pues caso con confesa» ${ }^{48}$.

As for Juan de Herrera, Jr's admission to the city council as a regidor, Alonso de Rojas continued:

«Esta entendido por toda esta ciudad pequeños y mayores que dio mil ducados en dinero a cierta persona [el corregidor] que le pudo sufragar para que probaje limpieza no teniendo gota de sangre limpia y no puede tenerla" ${ }^{49}$.

This accusation was echoed by the cathedral chaplain Rodrigo de

${ }^{46}$ Ibid., witness 4 , second hearing.

${ }^{47}$ Ibid., witness 6, second hearing.

${ }^{48}$ Ibid., witness 8, second hearing; “because [Francisco Sedeño] married Jerónima de Herrera, and all Jerónima's brothers and sisters are [married to] confesos and descendents of Jews; as a likely consequence one could assume and suspect that the father of Gabriel Sedeño was a confeso since he married a confesa".

49 Ibid.; "It is understood throughout the city that he gave to a certain person [the corregidor, which is still visible but scratched out in the original document] 1,000 ducats". 
Ávalos, who gratuitously complained that the admission of Juan de Herrera, Jr., as a regidor after the crown ordered that a pure blood statute be enacted in the Toledo city council had caused another scandal in the city.

The four humblest witnesses - an apothecary, a citizen, a farmer, and a surgeon - all testified to Juan de Herrera, Sr's untainted lineage, as did the maestrescuela, Antonio de Covarrubias, and the prebendary and secretary of the Inquisition, Juan Bautista de Chaves. While numerically outvoted, they gained an important supporter with the corregidor Alonso de Cárcoma. The corregidor based his testimony on an investigation carried out by Gaspar de Robles, a Toledo regidor and familiar of the Holy Office, which concluded that Juan de Herrera, Jr., was' of pure blood. To explain his decision and "to unburden his conscience", the corregidor offered the following homily:

«En este lugar ay gente de tan mala inclinacion que se ofresceran a defamar en esta y en otras informaciones como se? [esta?] a decir contra la limpieza y calidad de hombres limpios y principales y honrrados, porque a este que declara an venido muchas personas deste lugar a poner faltas y defectos en la calidad y limpieza de muchas personas graves y principales en quien no cabe ni ay las tales faltas; de donde infiere que es conveniente andar con recato en semejantes diligencias y para la verificacion dellas hecha mano de gentes que no sean apasionadas y que sean christianos temerosos de dios» ${ }^{\text {so. }}$.

The corregidor was correct when he said that many people in Toledo were willing to accuse others of impure blood, and he was wise in his decision to proceed with caution. But it is likely that his posture of circumspection was influenced by the money $-1,000$ ducats - that some witnesses accused him of accepting from the candidate, an arrangement not mentioned by Alonso de Cárcoma in his testimony. In addition, Gaspar de Robles, the man who carried

so Ibid., witness 21, second hearing; "In [Toledo] there are people of such evil inclination that they offer to defame, in this and in other hearings, the purity and quality of pure, prominent, and honorable men. Many people have come [to me] from [Toledo] to allege faults and defects in the quality and purity of many grave and prominent persons who do not have such faults. From this I infer that it is wise to proceed with circumspection in such procedures, and for verification to use people who are not prejudiced and who are Christians fearful of God». 
out the investigation of the lineage of Juan de Herrera, Jr., was himself of dubious lineage, and in later years the name Cárcoma appears as a surname for a son of the Franco family, suggesting that while the corregidor was in office he formed a marriage alliance with another wealthy converso family of Toledo. Money, combined with friends and relatives in high places, allowed many conversos to achieve and secure their upward mobility, and in many cases to make a mockery of the pure blood statutes.

For a reader with no knowledge of the Herrera-Santo Domingo family, it would be difficult to know what conclusions to draw from the conflicting evidence presented in this case. If in the second hearing the majority confirmed the converso origins of Gabriel Sedeño's mother, some witnesses did not, and the corregidor's speech put the motives of all the adverse witnesses in doubt. However, in this case the majority was correct. The amount and degree of perjury, most obviously in the first trial but also in the second, is striking. That the more humble citizens might not know the origins of Juan de Herrera is credible, but it is highly doubtful that maestrescuela Antonio de Covarrubias, the corregidor, or the secretary of the Inquisition, who had access to all the inquisition documents, would not know. Possibly they were all bribed, or possibly they wanted to help a fellow traveller or to express their dislike of the pure blood syndrome. One apparent result of the pure blood statutes was the creation of a sizeable number of perjurers.

By the 1590s the Herrera family could boast a member in two institutions that had pure blood statutes, but is their experience an exception or the norm? In the case of enforcement of pure blood statutes in the Toledo city council, their experience appears to be typical. The Herreras retained their office of regidor until 1629, when this branch of the family died out. The Franco and Hurtado families also continued on as regidores into the seventeenth century. While the office occupied by Diego Hurtado was eliminated when he died in 1567, it was re-created in the form of a new office known as the depositario-general that was bought by another converso, Juan Sánchez de Cisneros, for 2,500 ducats ${ }^{51}$. Francisco Sánchez de

51 AGS, DGT, leg. 322; AMT, Libro de regidores. For the origins of Juan Sánchez de Cisneros, see L. MARTZ, "Converso Families", pp. 150-151, 185, for the CisnerosHusillo family. M. Cuartas Rivero, "Ventas», pp. 251-253 for information about the sale of offices and the responsibilities of the depositario general. 
Toledo had no children, so the continuity of this family ended with his death. With the military orders things were a bit riskier. One can cite more deserving candidates than Gabriel Sedeño who were refused a habit because of their tainted lineage ${ }^{52}$, but Gabriel Sedeño was not the only Toledano of converso origins to boast a military habit, even before the opening up period initiated by the count-duke of Olivares in the seventeenth century.

However one chooses to interpret the pure blood statutes, their effectiveness in keeping conversos out of desirable institutions or corporations is as questionable in the sixteenth century as it was in the fifteenth century. This is not to say that the statutes were without effect. As the seventeenth century wore on, men like Juan de Herrera, Sr., proud of their accomplishments and their middleclass or citizen status, slowly faded from view. The deteriorating economic conditions in Castile from 1580 onward certainly played a role in fortifying the deleterious values embodied in the pure blood statutes - no business activities or demeaning physical labor, such as sweeping shopfloors; no paying of taxes; and Old Christian origins, best demonstrated by distant forbears from the north of the Peninsula. By 1650 , citizen regidores were a thing of the past in the Toledo city council, and nearly all the regidores were members of a military order or familiares of the Inquisition. The irony is that many of these men were descendents of those against whom the pure blood statutes were aimed. For a variety of reasons, in the seventeenth century they chose to seek the titles and adopt the lifestyle that had come to be associated with pure blood.

By concentrating on a family that chose to maintain its ethnic identity, this paper may have the regrettable effect of strengthening another common misconception: that the upper levels of Toledo society can be neatly divided into Old and New Christians. This is not the case, for intermarriage between the two groups occurred in the fifteenth century and continued on into the sixteenth century. This, however, is another topic to be explored in the future.

52 J. I. GuTiÉRREZ NiETo, "Inquisición y culturas", pp. 696-698 for the case of Sancho Dávila who was denied a habit of Santiago because his grandmothers were conversas. 


\section{RESUMEN}

El artículo trata de los estatutos de limpieza de sangre en la ciudad de Toledo, especialmente los impuestos por la Corona en el Ayuntamiento en 1566, y de cómo estos estatutos afectaron a algunos conversos. En el análisis se incluyen las ventas de oficios municipales y de títulos de hidalguía por la corona y el prestigio social de algunos converos que compraron regidurías antes de 1566. Se toma como ejemplo una familia toledana para demostrar las preferencias de algunos conversos ricos en materia de alianzas matrimoniales, así como los medios que emplearon los conversos para superar los intentos de excluirlos del Ayuntamiento y de otros puestos relevantes.

\section{SUMMARY}

This article is concerned with the pure blood statutes in the city of Toledo, particularly those imposed by the crown on the city council in 1566, and how the statutes affected some conversos. Included in the analysis are the sales of municipal offices and titles of hidalguia by the crown, and the social status of some conversos who brought regidurías before 1566. One Toledo family is used to demonstrate the marriage alliances preferred by some wealthy conversos and the means by which conversos overcame efforts to exclude them from the city council and other positions of status. 